\title{
7 Financial Systems to Make Savings Count
}

In advanced economies, the vast majority of savings are intermediated through formal financial instruments. This intermediation can take one of three forms: direct financing, with individuals holding instruments issued directly by firms or the government; through institutional investors who then invest in those instruments; or through formal financial intermediaries such as banks. By contrast, in Latin America and the Caribbean, much of the savings of households does not go through the formal financial system. Some households-typically the less wealthy-keep savings in unregulated institutions, buy durables or other assets as a means to save, or simply stash their cash in the proverbial mattress. Others-typically more wealthy households-hold assets abroad or invest in real estate, bypassing the domestic financial system entirely.

Latin American and Caribbean financial systems lack depth and pose serious constraints to access credit. ${ }^{1}$ Restricted credit is the other side of the coin of low savings in formal financial instruments or institutions. Indeed, as Levine's (2005) comprehensive review of finance and development makes clear, financial systems have five closely interrelated roles: to produce information ex ante about possible investments and allocate capital to them; to monitor investments and exert corporate governance after providing finance; to facilitate the trading, diversification and management of risk; to mobilize and pool savings; and to ease the exchange of goods and services. ${ }^{2}$

This chapter focuses on financial intermediation and mainly on the fourth role: to mobilize and pool savings. It asks why in Latin America and the Caribbean, the financial system has done a poor job in this role. 


\section{In Financial Systems, Small Is Not Beautiful}

An efficient financial system should promote savings by providing easy and convenient access to appropriate savings instruments offered by high-quality, trustworthy institutions at reasonable cost. Clearly, there is no single optimal design for a financial system; many potential instruments and structures of financial systems may be equally efficient. ${ }^{3}$ Comparing the very different financial systems of successful, advanced economies with different savings rates and deep financial systems confirms this point.

In some systems (such as the United States and the United Kingdom), direct financing through capital markets is relatively more important. Firms issue equities and bonds, which are bought by individuals or by institutional investors that pool the savings of individuals. In other countries, such as Germany and Japan, financial intermediaries, including banks, are relatively more important. They offer savings accounts and provide financing to firms. Banks play a critical role in allocating capital and in guiding the corporate governance of firms through representation on boards. Financial systems dominated by capital markets are often characterized as having "arms-length" financing because equity market valuations-and at the limit, hostile takeovers-play a disciplining role, as opposed to the more direct monitoring role played by financial institutions in systems dominated by banks. ${ }^{4}$ However, in all advanced economies with deep financial systems, both direct financing and financial intermediaries exist; the question is not so much one or the other but the balance between the two and the precise and more subtle roles that each may play. ${ }^{5}$

In Latin America and the Caribbean, banks have tended to dominate the financial landscape, although capital markets have been growing. Most individuals do not buy equities or bonds directly, but rather hold them indirectly through mutual funds, pension funds, or insurance companies. The size of these institutional investors in the region has increased, and they are now very significant players in some countries.

Most financial savings in the region are held in banks and other financial institutions. On average, the deposits of banks exceed the total assets held by pension funds, mutual funds, and insurance companies combined in Latin America and the Caribbean (see Figure 3.1). The financial depth in the typical country in Latin America and the Caribbean lags far behind countries like the United States, with its expansive array 
Figure 3.1 Financial System Deposits and Assets under Management of Different Institutional Investors

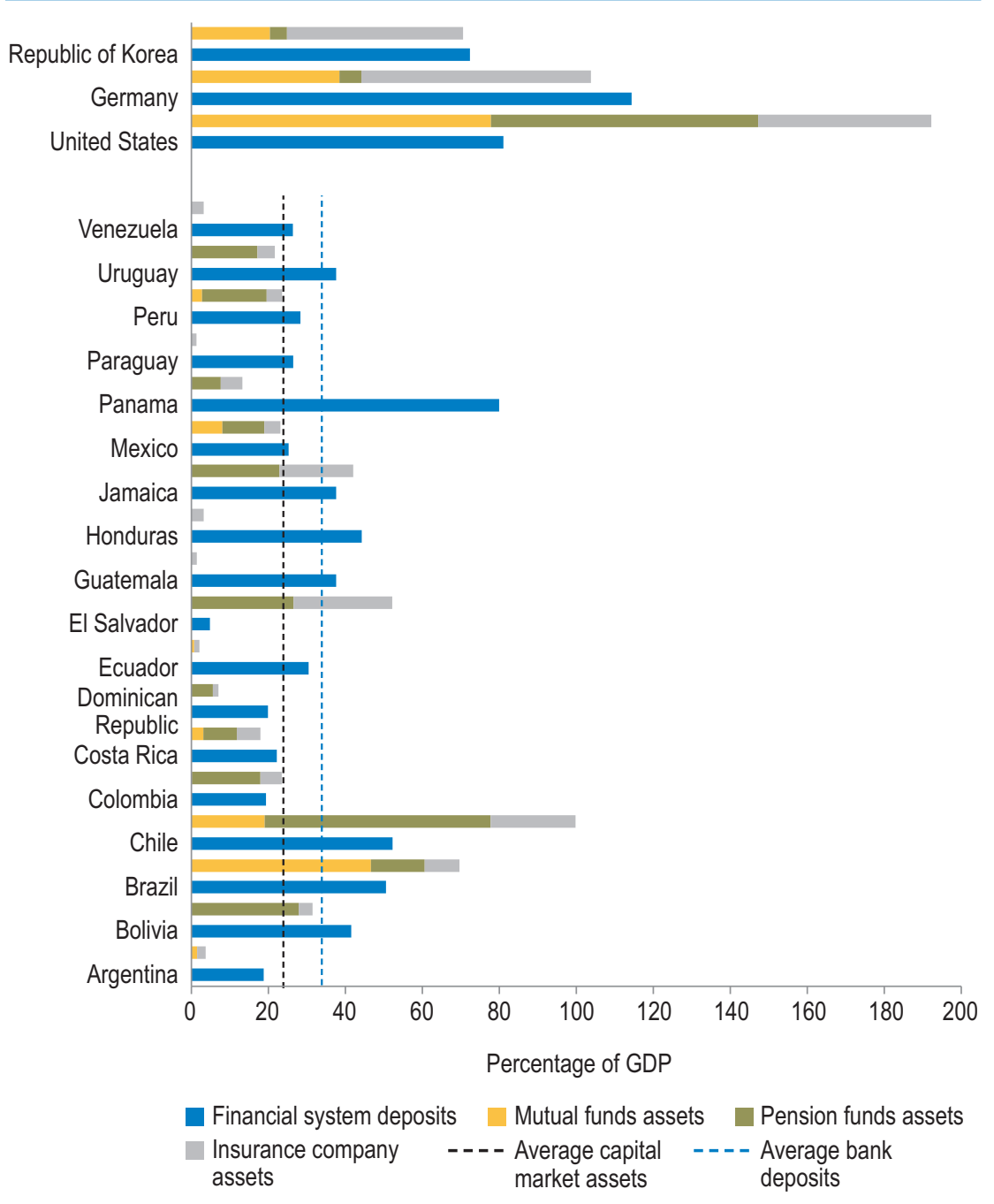

Source: Authors' elaboration based on data from Bebczuk (2015b).

Note: Data on assets rather than liabilities are used for mutual funds and pension funds, as these are the data available on a comparative basis. The figures have been adjusted for double-counting (as mutual funds, pension funds, and insurance companies may hold bank deposits, and banks may purchase mutual funds) as data sources allow, although it is possible that some may remain. For details, see Bebczuk (2015b).

of institutional investors, and Germany, where banks are relatively much larger, and even the Republic of Korea where banks and institutional investors are roughly on a par. 
Countries vary considerably in the region in terms of the management of deposits and assets (see Figure 3.1). For example, in Brazil, the mutual fund industry has grown considerably and has assets under management approaching total banking sector deposits. In Chile, pension fund assets exceed bank deposits, and the sum of insurance company and mutual fund assets is close behind. Mexico has a large corporate bond market. These assets are typically held by pension funds and mutual funds, which together rival the amount held in bank deposits. And in Colombia, pension fund assets under management are almost comparable to the deposits of banks.

How are financial systems in the region likely to change as capital markets grow ${ }^{6}$ More capital market-based financial systems tend to promote transparency and information, which is generally considered a benefit. On the other hand, they may also promote greater instability. Writing in 2002 before the global financial crisis about a similar phenomenon in continental Europe, Rajan and Zingales (2003) warn about this trade-off. Still, Latin America and the Caribbean has experienced significant economic instability in its past, despite having a more bank-based financial system; indeed, as a result, the region has improved banking and capital market supervision and has been extremely conservative in its regulation of more exotic financial instruments. This approach surely helped the region survive the recent global financial crisis relatively well (Powell, 2015). It may also allow the region to transition to a more market-based system while maintaining financial stability.

A related question is whether as capital markets grow they will take over from intermediaries-or, in other words, whether capital markets are substitutes or complements to financial institutions. ${ }^{7}$ Given the changing landscape and the diversity in the region, Latin America and the Caribbean provides fertile ground to analyze this question. A novel analysis suggests that for Latin America and the Caribbean-as for the rest of the world-banks and capital market institutional investors are complements, rather than substitutes. ${ }^{8}$ What this means is that banks and capital markets have been growing together. Capital markets are not taking over from banks, although both grow more quickly in some countries than others. The region appears to be no different from the rest of the world in this regard.

For capital markets to grow, ultimately outside investors must feel comfortable either buying debt-type instruments or investing in equity issued by firms. In turn, this requires a set of conditions to be met. 
Good information regarding firms' activities must be available. Financial accounts must be meaningful and transparent, which in turn means that auditors are doing their job and are being sanctioned if they don't. Rating agencies should be operating effectively; this saves individual investors the work of analyzing every firm, which would be prohibitively costly. Corporate governance should be effective so that outside equity or bond investors do not feel they will be taken advantage of by an inside group of equity holders. ${ }^{9}$

Latin America and the Caribbean typically scores rather poorly on these important aspects of what might be referred to as the plumbing that allows finance to flow freely from investors to users. This may be one reason why financial markets have remained small to date, and why financial intermediaries, particularly banks, continue to dominate. Indeed, one of the roles of financial intermediaries is precisely to "represent" small investors, given their likely lack of influence on firms. ${ }^{10}$ Financial intermediaries may then play a very important role in increasing the quantity of financial savings. But in order to do this, they must build solid reputations so that investors feel comfortable entrusting them with what may be their life savings. They must also offer convenience and appropriate instruments with a reasonable return.

Despite recent growth, banking systems in the region remain relatively small compared to GDP, especially compared to other bankdominated systems. Macroeconomic instability and weak creditor rights are frequently cited as underlying barriers to greater financial depth. ${ }^{11}$ While the median banking system in the region has grown to have almost 40 percent of GDP in deposits, this remains much lower than the banking system of the median OECD and Southeast Asian economy. Moreover, as the region contains a number of smaller economies, the absolute size of financial systems in the region is considerably smaller than that of comparators. The median banking system in the OECD has some $\$ 300$ billion in deposits compared to only $\$ 15$ billion in deposits in Latin America and the Caribbean (Figure 3.2).

Large financial systems have two very important advantages. The first is economies of scale, which allow large banks to operate with low margins. ${ }^{12}$ This can mean higher returns for savers and lower costs for borrowers-unless the rents are captured by bankers. The second advantage is that such systems can mobilize large amounts of financing for big projects; they can overcome problems of indivisibility. Large projects may require considerable financing, which may be a constraint 
Figure 3.2 Median Banking System, OECD and Latin American and Caribbean Countries

a. Loans and Deposits (billions of US dollars)

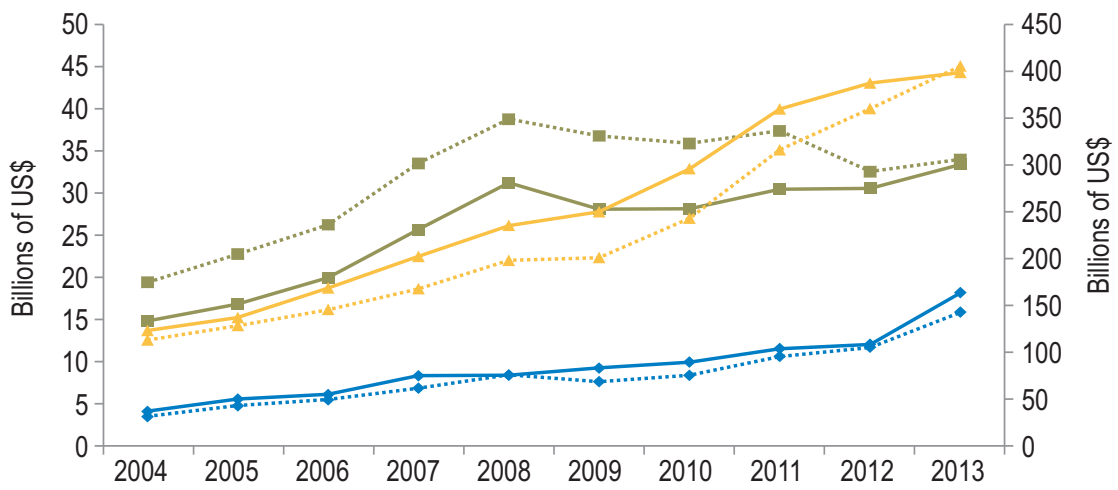

$\longrightarrow$ Latin America and the Caribbean (left axis) — Outstanding commercial deposits

$\longrightarrow$ - Advanced economies (right axis)

........ Outstanding commercial loans

- Emerging Asia (right axis)

\section{b. Loans and Deposits (percent of GDP)}

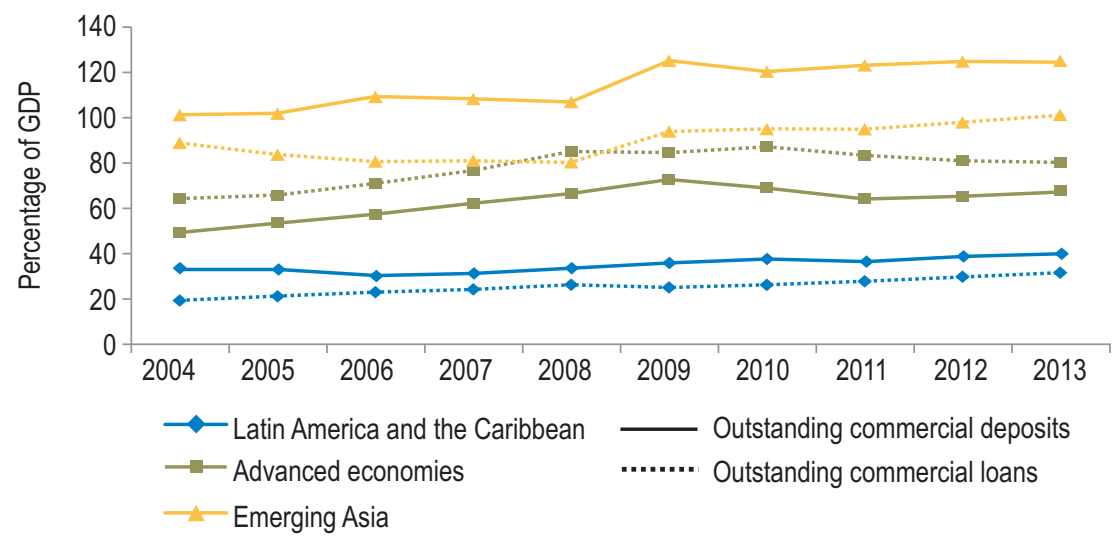

Source: Authors' elaboration based on data from Financial Access Survey, IMF. Note: See endnote 3 of chapter 2 for the list of countries in each country group.

in some countries that lack large financial intermediaries..$^{13}$ The impact of scale on costs is considered in more depth in Chapter 11.

\section{Formal vs. Informal Saving: Quality Counts}

How financial intermediaries operate determines not only the quantity of savings, but also the quality. To increase the quality of savings, the 
intermediary should be fully integrated into the country's financial system. This ensures that the savings are allocated efficiently, which in turn allows them to offer better returns. Institutions should also be regulated appropriately and should have a high standard of corporate governance so that capital can be allocated efficiently.

The previous section focused on formal financial markets and formal financial intermediaries. But in Latin America and the Caribbean, savings through more informal mechanisms make up a sizable part of the financial assets of many households. On average, 48 percent of households in the region report some savings (Figure 3.3, panel a), and 45 percent say they have an account in a formal financial institution, but only 16 percent report saving in formal institutions (panel b), according to data collected by the World Bank's FINDEX dataset. ${ }^{14}$ These averages put Latin America on the level of Sub-Saharan Africa (a region with significantly lower income per capita) and pale in comparison to Advanced Economies and Emerging Asia (see Figure 3.3).

Where does the rest of the savings go? A fraction is channeled through informal financial institutions. In fact, considering both formal and informal financial institutions, the composition of Latin America and the Caribbean's financial systems is complex. Most countries have a large number of small, cooperative-type financial institutions. On top of this, other types of institutions, including nongovernmental organizations (NGOs), provide financial services. Microfinance institutions have grown considerably in several countries of the region, and some of them also offer deposit-like instruments (Trujillo and Navajas, 2014). Typically, these smaller institutions operate only in a particular locality or region, and may not be highly integrated into countries' financial systems. ${ }^{15}$ Since relatively poor households save using these alternatives, the aggregate amount of deposits in these institutions may be smaller than deposits at formal banks; however, they are very significant in terms of the number of accounts and the savings portfolios of those poorer households. If savings are highly dispersed-in either small formal or informal financial institutions-and not pooled, then they may not be allocated in the most efficient manner. In turn, the returns offered to savers may be low, reducing the total amount of savings. ${ }^{16}$

As panel a of Figure 3.4 shows, there are 604 commercial banks in 20 countries in the region, with deposits amounting to about 42 percent of GDP. Almost 2,000 non-bank regulated financial institutions hold about 2 percent of GDP in deposits, and around 4,000 non-regulated 


\section{Figure 3.3 Financial Inclusion by Region}

\section{a. Percentage of People Who Saved any Money}

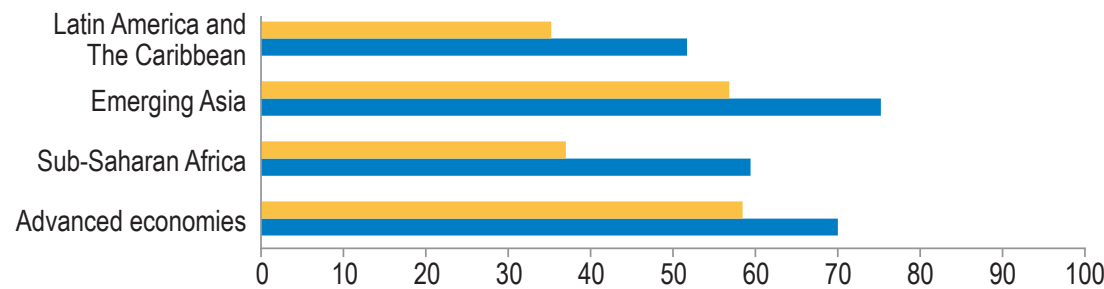

\section{b. Percentage of People with Account in a Financial Institution}

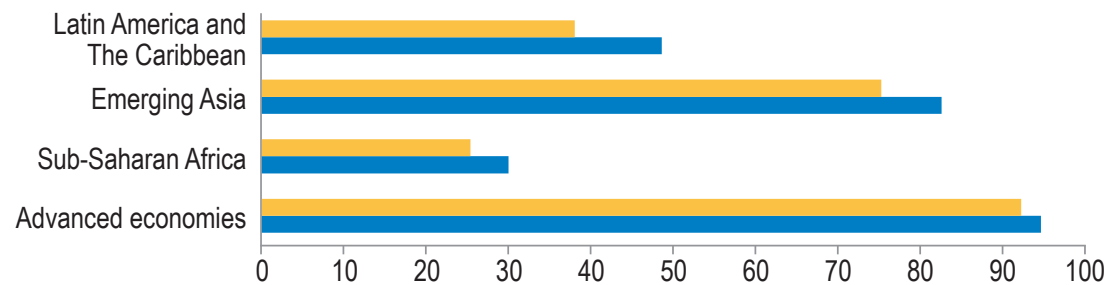

\section{c. Percentage of People Saving in Financial Institutions}

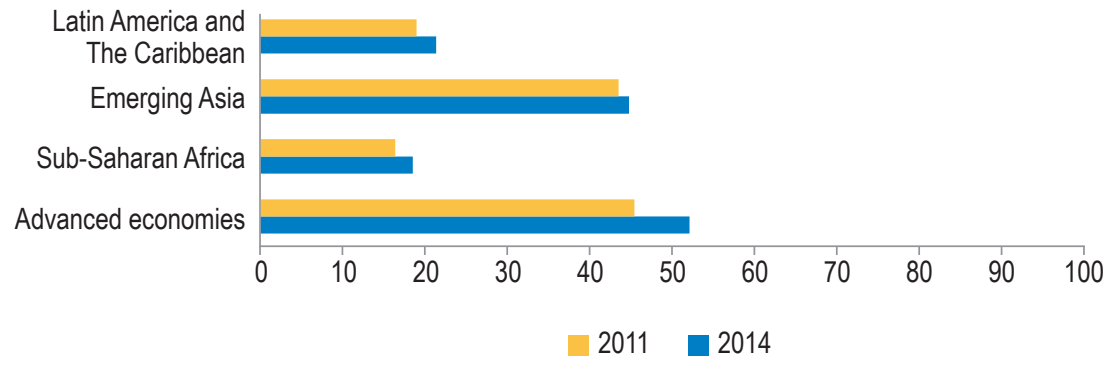

Source: World Bank, Global Financial Inclusion Database (FINDEX).

Note: All measures are simple country averages. Panel a, Save any money in the past year: Denotes the percentage of respondents who report saving or setting aside any money in the past 12 months (percent of respondents age 15+). Panel b, Account at a financial institution: Denotes the percentage of respondents who report having an account (by themselves or together with someone else) at a bank or another type of financial institution (see year-specific definitions for details) (percent of respondents, age 15+). Panel c, Saved at a financial institution: Denotes the percentage of respondents who report saving or setting aside any money at a bank or another type of financial institution in the past 12 months (see year-specific definitions for details) (percent of respondents, age 15+). See endnote 3 of Chapter 2 for the list of countries in each country group.

institutions hold a further 2.2 percent of GDP in deposits. Among the non-bank regulated financial institutions, 10 development banks and 14 investment banks have total deposits of 0.2 percent of GDP (panel 
Figure 3.4 Types of Financial Institutions: Number and Share of Savings as Percentage of GDP

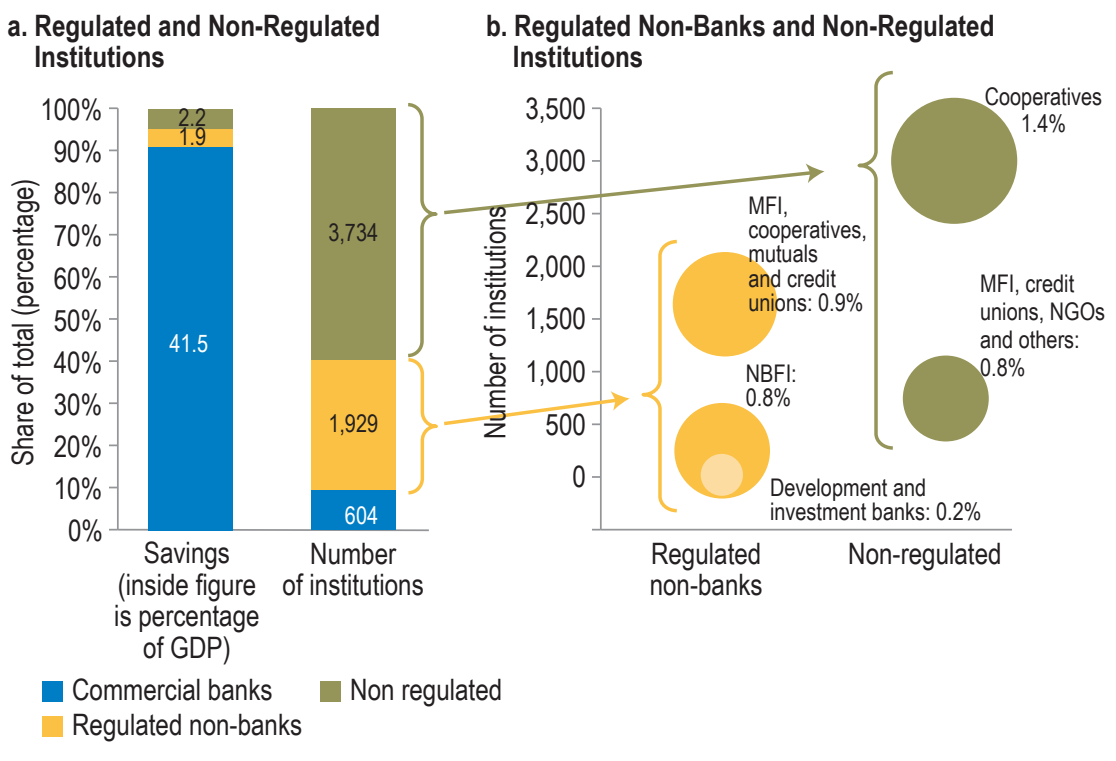

Source: Authors' calculations using data from Trujillo and Navajas (2014).

Notes:Panel a: Vertical axis shows percentage of total. Figures inside first column show savings as percentage of GDP, simple average across countries in the region. Figures inside second column show the total number of institutions. Panel b: Bubble size illustrates the average of savings as percent of GDP, simple average across countries.

$\mathrm{MFI}=$ Microfinancial Institutions.

$\mathrm{NBFI}=$ Non-Bank Financial Institutions. Include: Financial companies/corporations, mortgages institutions, trust companies, private financial fund in Bolivia, off-shore entities in Guatemala, SOFOMERs (Sociedades Financieras de Objeto Múltiple entidades reguladas) in Mexico, saving and lending society, rural financial Institutions, IFEs (Instituciones Financieras Externas) in Uruguay.

Non-Bank Regulated Institutions include: Development and investment banks, NBFI, MFI, cooperatives, mutuals and credit unions.

GDP series used: 2013 GDP in current US\$ (Source: WDI).

Countries included: Argentina, Barbados, Belize, Bolivia, Brazil, Chile, Colombia, Costa Rica, Ecuador, El Salvador, Guatemala, Haiti, Honduras, Mexico, Nicaragua, Panama, Paraguay, Peru, Republica Dominicana and Uruguay. Bahamas and Venezuela excluded due to lack of complete data.

b). There are 116 microfinance institutions (MFIs); 1,413 cooperatives; 14 mutual funds; and 104 credit unions. Together, their deposits amount to about 1 percent of GDP, on average. The non-regulated institutions are mostly cooperatives (almost 3,000 of the 4,000 non-regulated institutions in the sample); their deposits amount to 1.4 percent of GDP. Deposits among the remaining non-regulated institutions account for 0.8 percent of GDP.

In addition, households may be saving in the form of non-financial assets, ranging from jewelry and consumer goods, such as refrigerators and cars, to houses and other property. They turn to these alternatives for 
a number of reasons. They may lack documentation to open an account; they may live far away from a financial institution; opening or servicing an account may be too expensive; or they may simply lack information or trust in financial institutions. In countries where people tend to mistrust the financial system-either because a history of relatively high inflation has eroded the real value of savings, or banking crises have wiped out financial savings-savers may seek to protect the real value of their savings by investing in assets with a better track record as a store of value. ${ }^{17}$ In the case of Argentina, a substantial portion of savings is channeled through the real estate market (see Box 3.1).

Saving in real estate is more common among high-income households. As Chapter 2 noted, poor households rely heavily on informal saving strategies, which include keeping money at home or with family/friends, saving groups, providing loans to other individuals, buying and holding jewelry and other assets, and investing in family businesses. The use of these mechanisms is especially common among households that in turn are more likely to be excluded from formal financial systems. Again, while these forms of saving may not constitute a large part of total national savings, they can be an important component of the savings portfolio of individual households.

Poor and middle-income households in Brazil, Mexico, and Peru are more likely to make monthly deposits into informal saving instruments than use bank accounts or other formal instruments, according to data collected through targeted financial surveys (see Chapter 2).In Mexico and Peru, 20 percent and 33 percent of all surveyed households report saving through a variety of informal mechanisms, while 14 percent and 30 percent of them save using bank accounts, respectively. In Brazil, on the other hand, the saving rate is low irrespective of the instrument: only 4 percent of the surveyed households save informally, while 10 percent of them do so formally. Preliminary evidence from Colombia reveals a pattern similar to that in Mexico and Peru: ${ }^{18}$ of the 16.5 percent of people who reported saving in 2013 , only 25 percent saved through formal instruments.

Figure 3.5 shows how savings are distributed in Mexico, Peru, and Brazil by saving instrument and portfolio among those who save and hold positive savings stocks. ${ }^{19}$ Several patterns are clear. First, the vast majority of surveyed households that save informally in these three countries do so mostly through family, friends, savings groups, or loans to others, and much less by buying assets for the home or business. Second, 


\section{BOX 3.1. ARGENTINA'S RESIDENTIAL REAL ESTATE SECTOR: A MAGNET FOR SAVINGS ${ }^{a}$}

In the context of high macroeconomic volatility, residential real estate has been a popular investment for savers. After the financial crisis of 2001-02, in which the government and many private institutions restructured debts, and many financial contracts were switched from dollars to pesos, Argentines increasingly channeled their savings toward real estate.

As shown in Figure B3.1, from 1992 until 2000, term deposits at banks rose by an average of $\$ 7.6$ billion per year, while from 2003 until 2012 they rose an average of only $\$ 2.2$ billion per year, a 70 percent reduction. On the other hand, new savings channeled to real estate soared 78 percent (these figures are in constant US dollars of 2014). During the first period, for each dollar that went to real estate, about six dollars went to new term deposits. During the second period, for each dollar that went to real estate, only 99 cents went to new term deposits.

In the city of Buenos Aires, while saving flows into real estate were about 8.4 percent of total savings from 1992 to 2001, they rose to more than 13.3 percent of savings in the 2003-2012 period, a 57 percent rise in the ratio (see Figure B3.2).

Moreover, the real estate market absorbed 27 percent more square meters comparing the decade from 2003-2012 with that of 1992 to 2001 . How did the real estate market react? Cruces (2016) finds that real rental rates fell signifi-

\section{Figure B3.1 Allocation of New Savings: Real Estate vs. Banks}

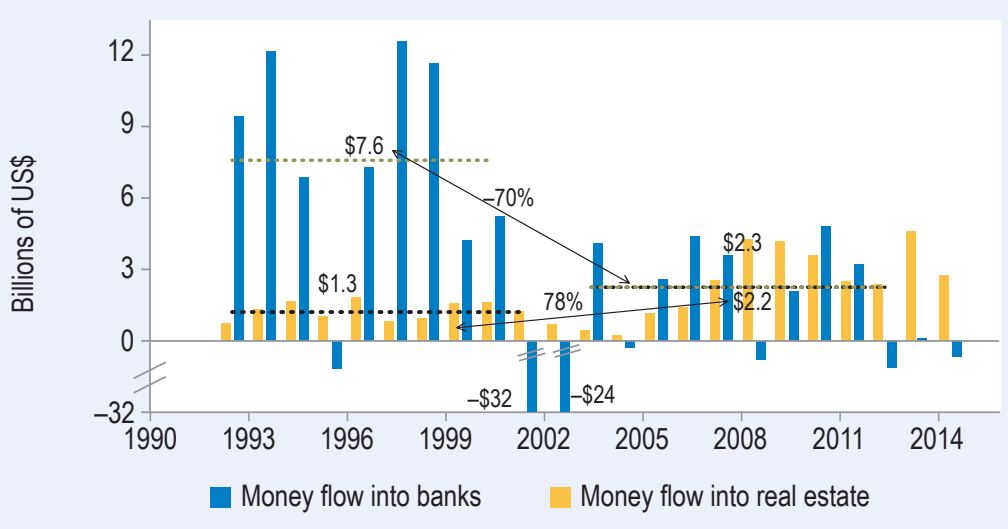

Source: Authors' elaboration based on Cruces (2016).

Note: This figure compares the flow of new savings channeled to real estate with that channeled to banks' term deposits. Flows into real estate only pertain to the City of Buenos Aires, while the increase in time deposits corresponds to the whole banking sector of the country. As a reference, the City of Buenos Aires accounted for about one-quarter of national GDP during both periods. All figures are in constant 2014 dollars. 
BOX 3.1. (continued)

Figure B3.2 Savings Channeled to Real Estate as a Fraction of City and National Savings

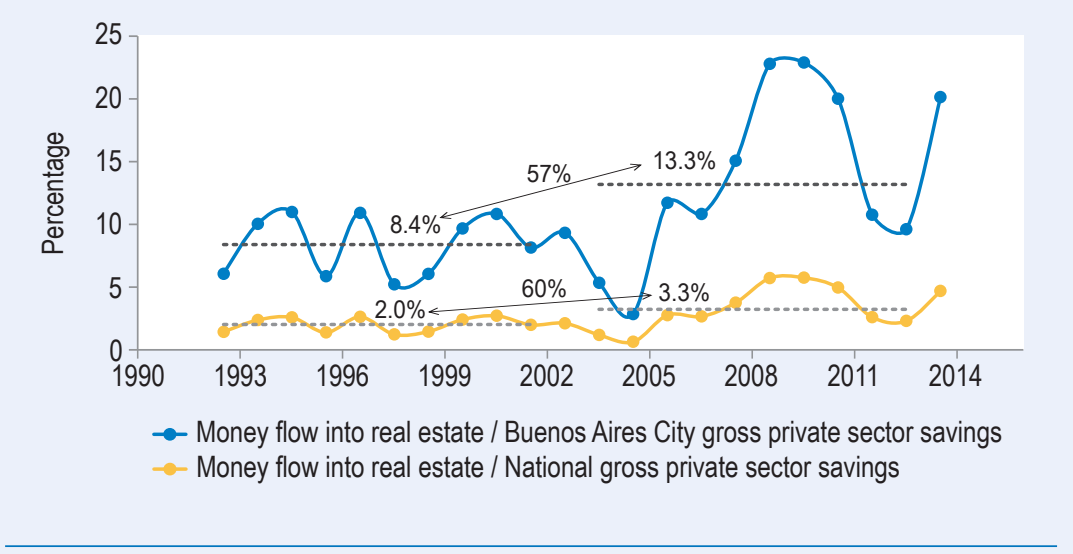

Source: Authors' elaboration based on Cruces (2016).

cantly to adjust supply and demand: the net rental rates fell from an average of 7.1 percent from 1992 until 2001 to a low of 2.7 percent since 2003. At the end of the sample, the net rental yield was just 1.5 percent per annum.

The net rental yield on housing can be compared to the returns on alternative investments to estimate the efficiency loss (opportunity cost) from the money sunk in real estate. A reasonable range of return for infrastructure investment for example would be 5 to 15 percent (see Campos, Serebrisky, and Suárez-Alemán, 2015). Using this benchmark implies an efficiency loss of between $\$ 0.8$ and $\$ 3$ billion dollars per year. The higher end of this range amounts to a loss of 2.5 percent of Buenos Aires city's GDP per year. While it may make sense to channel so much savings to real estate from the individual investor's standpoint, it is inefficient for the society as a whole. ${ }^{34}$

\footnotetext{
a This box draws from Cruces (2016).

b There are multiple caveats that come with this exercise. For starters, it is assumed that the entire stock of new housing was offered for rental. This is not necessarily the case. If people build new homes to occupy them, or to sell then to new occupants, then that has a subjective value to the owner. This notwithstanding, clearly rental rates went down because the market could not absorb all the new stock of housing. The analysis suggests substantial amounts of resources obtain very low yields in the real estate sector, while financing for productive investments is in short supply.
}

households that save formally use saving accounts and employee paycheck accounts, but not other financial instruments that can provide higher long-term returns, such as fixed-term deposits and mutual funds (the total share of long-term saving instruments among households 
Figure 3.5 Portfolio of Savings among Low- and Middle-Income Households

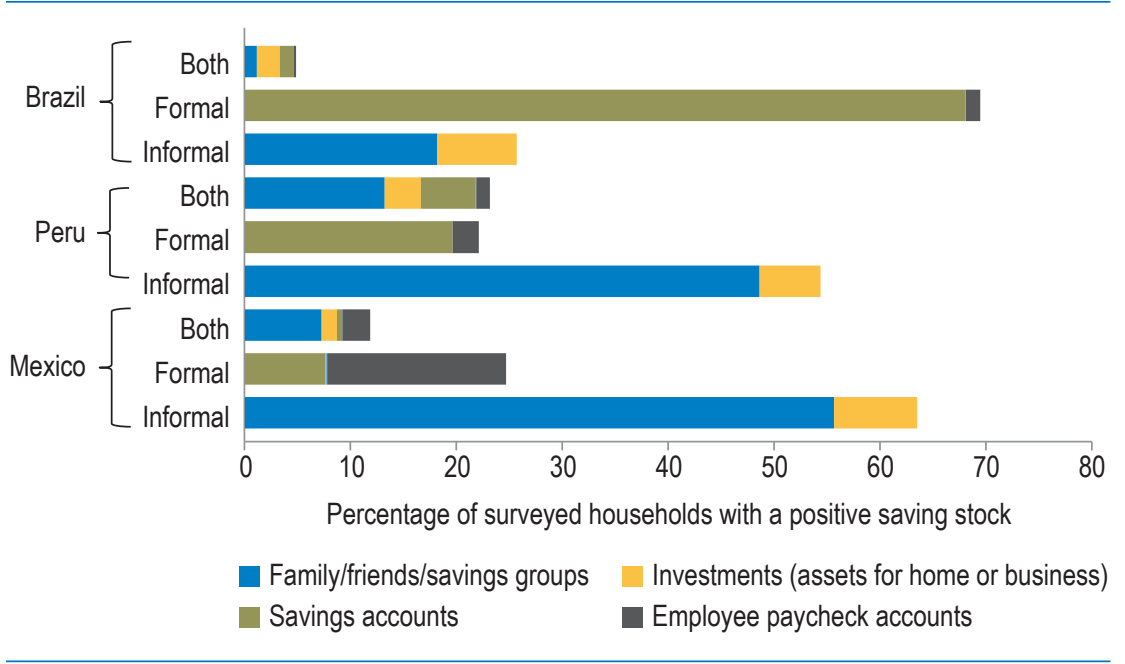

Source: Authors' calculations based on the Base of Pyramid (BoP) Survey.

saving formally is less than 0.5 percent). Third, households that save using both formal and informal instruments are the smallest group of savers in each country. ${ }^{20}$ Moreover, the portfolios of those households that do use both types of instruments also tend to favor informal saving instruments.

The pattern of saving choices among households in Latin America is very different from a textbook model whereby households save, deposit those savings in banks or other financial intermediaries, which in turn allocate those savings to those in the economy that need the funds to invest. But how different is Latin America from other regions in this respect? In order to address this question, the flow of funds of households in a subset of countries in Latin America and in a comparator group of developing countries outside the region was tracked.

The flow of funds analysis separates the sources and uses of households' funds. Households receive funds from either "borrowing" or "saving." In turn, households use those funds to either "acquire financial assets" or "to invest directly;" for example buying physical (capital) goods for the household/family firm, or investing in a residential dwelling. ${ }^{21}$

A few interesting patterns emerge and are displayed in Figure 3.6. First, in terms of sources of funds, on average households in Latin America rely more on their own funds (savings) than on external funds 
Figure 3.6 Source and Use of Household Funds, Latin America vs. Comparators

\section{a. Household Financial Portfolios}

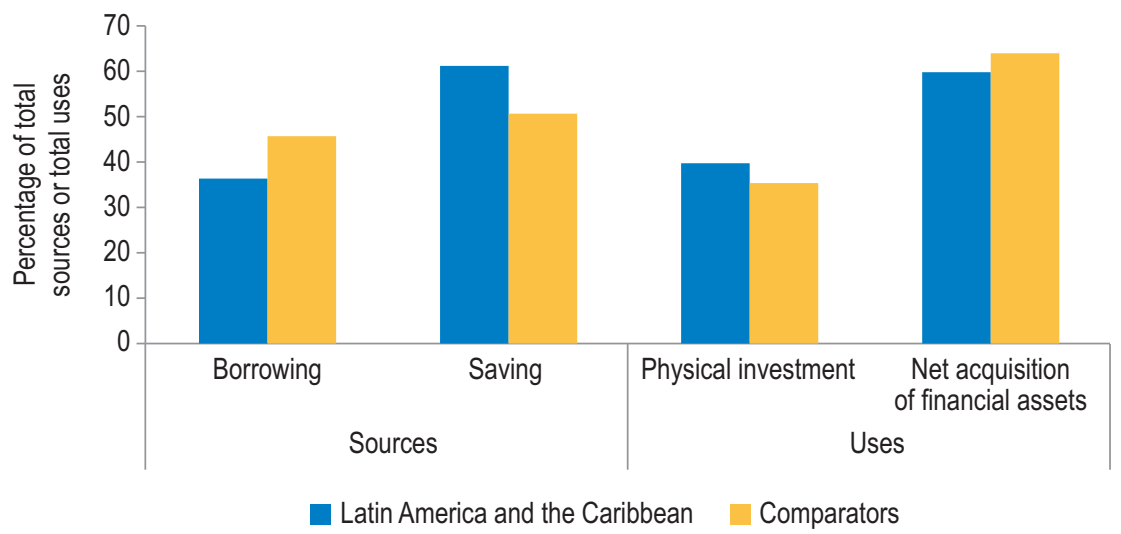

b. Net Acquisition of Financial Assets
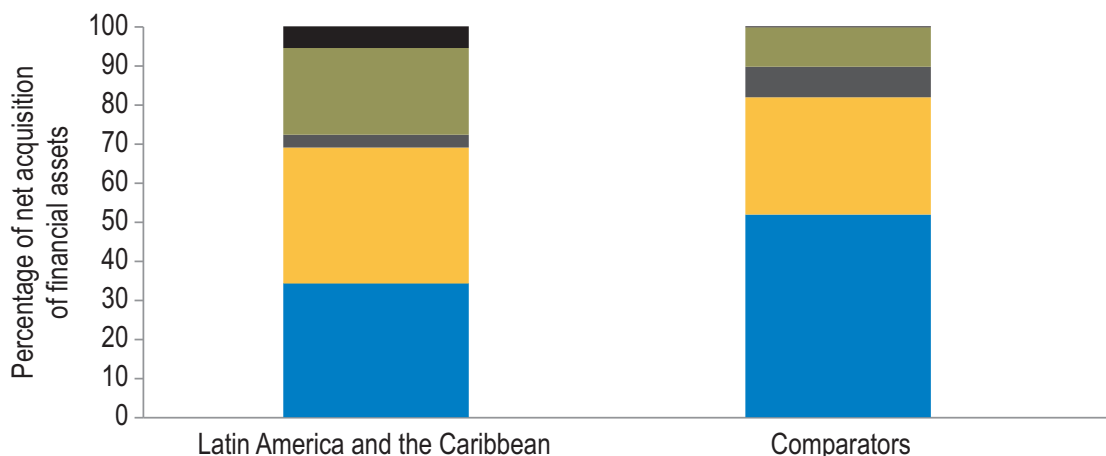

Financial deposits ${ }^{\mathrm{a}}$

Insurance and pension funds

Debt securities

Equity

- Other financial assets ${ }^{c}$

Source: Authors' calculations based on national accounts data from each country.

Notes: Computed as simple averages by country over the period 2005-2009.

a "Financial deposits" includes cash holding (for countries where deposits can be separated from cash holdings, the share of cash in the significantly smaller than deposits);

b "Equity" includes direct ownership of firms, equity securities and shares in mutual funds;

c "Other financial assets" is computed as a residual of "Net acquisition of financial assets" and the other sub-accounts.

(borrowing from banks or other sources). Roughly 60 percent of total available household funds come from their own savings compared to 50 percent among comparators (panel a). On the other hand, on average, households in Latin America invest approximately 40 percent of 
their funds directly in physical assets (mostly residential investments) and acquire financial assets with about 60 percent. Among the comparator group, the split is 35 to 65.

Second, within the category of "net acquisition of financial assets," the financial portfolios in Latin America tilt more toward instruments that are not necessarily intermediated by the formal financial system. Panel $b$ shows the distribution of total net acquisition of financial assets. ${ }^{22}$ In Latin America, average financial deposits account for approximately 34 percent of total purchases of financial assets, compared to more than 50 percent among the comparators. By contrast, "equity" accounts for 22 percent of the total net acquisition of financial assets in Latin America, compared to 10 percent in the comparator group. This category includes direct ownership of (family) firms, which is a non-intermediated financial asset, and which makes up the bulk of the account in those countries for which there are data. ${ }^{23}$ Therefore, on top of allocating a smaller share of funds to purchasing financial assets compared to households in the comparator group, households in Latin America are much more likely to select financial instruments that are not formally intermediated.

The regional averages, however, hide much heterogeneity across countries. For example, in Chile, which has the deepest financial system in the region, 50 percent of funds are channeled into financial deposits and other financial instruments, while only 9 percent goes toward equity. In Ecuador, which has a smaller financial system relative to the size of its economy, only 25 percent of funds are channeled into financial instruments, and 32 percent go into equity assets. More funds appear to be intermediated in Chile than in other countries in the region, where funds tend to be used more for direct investments. Chile more closely resembles a country like the Republic of Korea in the comparator group. For the other four Latin American countries, a significantly smaller fraction is intermediated through financial deposits and other financial instruments.

Mexico provides an interesting country to analyze in more detail. National saving (as a percent of GDP) is reasonably high given income per capita, and household savings constitute some 50 percent of the national total. Most of that savings, however, is not intermediated through the formal financial system (Székely, Mendoza, and Karver, 2015) When "financial saving" is decomposed into financial deposits, acquisition of fixed assets, and the purchase of durable goods, deposits (both through formal and informal financial institutions) represents 
less than 10 percent of saving, while the purchase of durable goods represents nearly three-quarters of all saving. The household saving rate (defined as a residual between disposable incomes and consumption) increases from 8.1 to 21.7 percent when durable goods are considered a form of saving rather than consumption (that is, when consumption of durables is excluded from consumption).

A high share of savings that is not channeled through an integrated formal financial system suggests that resources are being poorly allocated. An interesting question is why these savings are not intermediated. If the reason is "lack of demand" for formal instruments, i.e., due to lack of access, poor information or mistrust in financial institutions, then the household may benefit considerably by improving access, financial literacy or trust (see Chapter 9 for more on information and trust).

This chapter focuses on the issue of lack of supply, or access. If many households live far from a formal financial institution, then factoring the costs of travel and time may encourage each individual household to save in an informal instrument even if that instrument pays little in terms of private returns. That informal saving instrument may have very little social return as well, as it may not lead to a very productive investment opportunity. In this case, if a sudden change in access occurs-for example, a local bank branch opens or mobile banking becomes available-then informal savers may switch instruments and the social return from the extra dollar of savings (the difference between the new return and the previous very low return) might be very high.

A complementary explanation for low intermediation relates to the high informality in labor markets in Latin America and the Caribbean. McKenzie and Woodruff (2006) find that in Mexico self-employed poor individuals receive above market rates of return for very small capital investments. Not surprisingly, these self-employed individuals tend to reinvest heavily in their own family business, buying goods such as refrigerators, trucks, or any other type of durable good that could simultaneously satisfy a consumption need for the household and serve as a capital good for their home business. ${ }^{24}$ Unfortunately, McKenzie and Woodruff also find that with each additional investment, the marginal return declines steeply. Thus, these small capital investments may make sense for self-employed individuals or households but are an inefficient use of savings from an aggregate, economy-wide perspective. While no similar estimates of individual returns are available for other 
countries in the region, clearly Mexico is not the only country in the region with a large percentage of self-employed, informal entrepreneurs in the economy.

Informality in labor markets also creates a potential barrier to access formal financial instruments because labor income from informal sources is more volatile and is more likely to be paid out in cash. Evidence from surveys conducted in Brazil, Mexico, and Peru supports these patterns. A higher proportion of households working in the formal economy have access to formal saving instruments, while a higher proportion of informal workers save using informal instruments. In Mexico, 11 percent of households working in the informal labor market save formally compared to 34 percent of households working in the formal economy. In Peru, the gap is even larger: 16 percent versus 49 percent. In Brazil, this gap is negligible: 10 percent versus 11 percent.

\section{Accounting for the Unbanked}

Much has been written on the potential obstacles to accessing credit while the potential problems of accessing formal financial savings instruments have been less studied. The World Bank's 2014 Global Financial Development Report summarizes both sets of literature and analyzes the accompanying FINDEX dataset in order to determine the most important potential obstacles to greater financial savings, and hence to deeper financial intermediation. One interesting finding is the importance of cost and distance as significant deterrents to opening or using a bank account. ${ }^{25}$

Employing a cross-section of the 2011 FINDEX dataset, Rojas-Suárez, and Amado (2014) analyze similar issues, but specifically focus on Latin America to explain the region's "financial inclusion gap." They highlight three particular aspects: the quality of institutions, the level of income inequality at the macro level, and the level of education at the individual level.

Powell (2016) confirms the first set of results using the 2011 and 2014 FINDEX datasets. The variable "rule of law" (which is considered a proxy for the quality of institutions) and the country "Gini coefficient" (a measure of country inequality) are both significant in explaining the proportion of people that have an account in a financial institution. Stronger institutions and greater equality are associated with a higher percentage of individuals with accounts in financial institutions. 
Figure 3.7 Percentage of Households with a Bank Account, Institutions and Inequality

\section{a. Institutions (Rule of Law)}

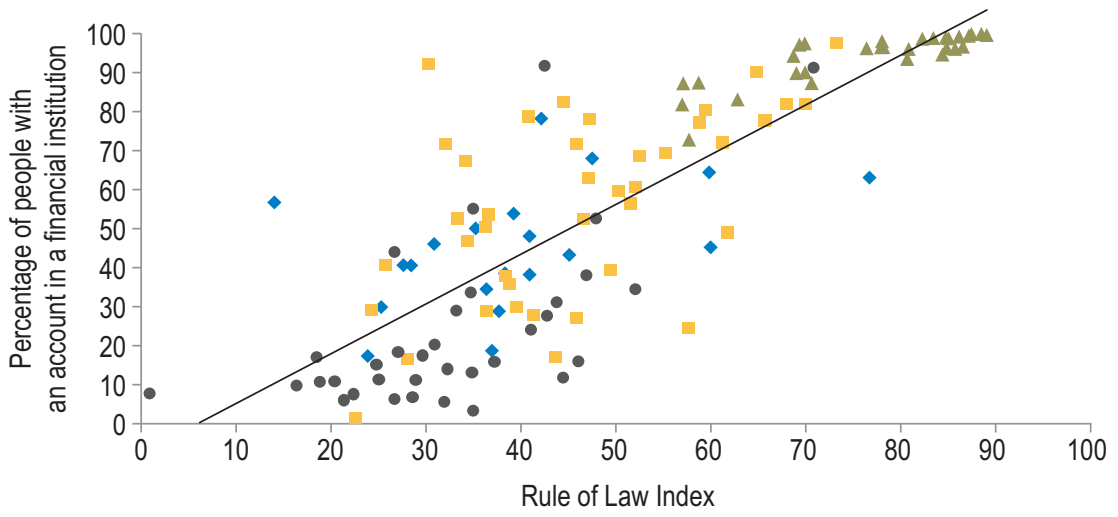

\section{b. Inequality (Gini Coefficient)}

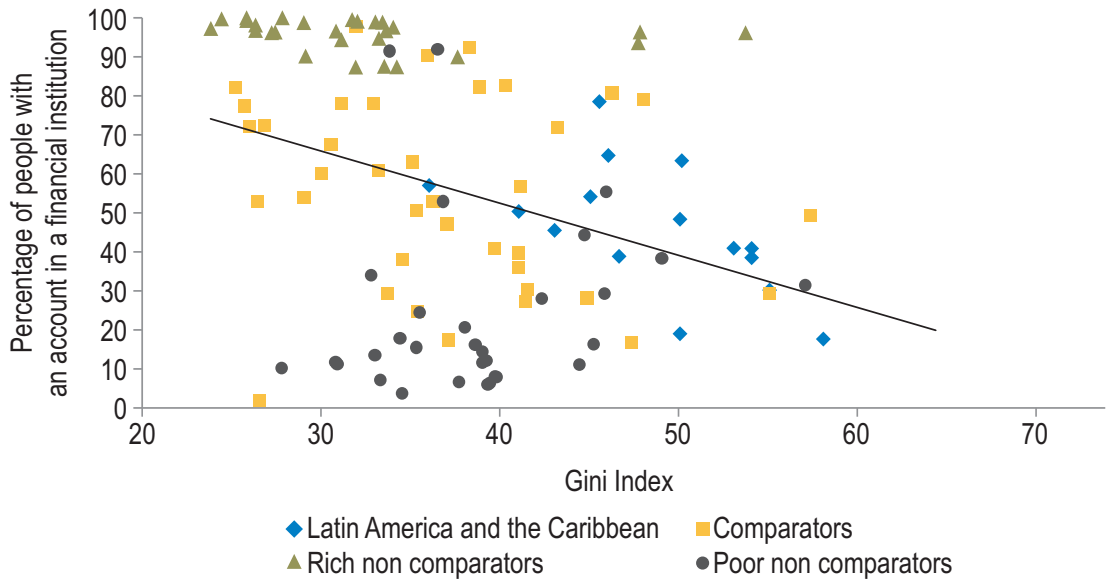

Source: Authors' calculations using the Findex Macro Database (World Bank, 2014b).

Note: Latin America and the Caribbean: Argentina, Belize, Bolivia, Brazil, Chile, Colombia, Costa Rica, Dominican Republic, Ecuador, El Salvador, Guatemala, Haiti, Honduras, Jamaica, Mexico, Nicaragua, Panama, Paraguay, Peru, Trinidad and Tobago, Uruguay and Venezuela.

Comparators: Albania, Algeria, Angola, Armenia, Azerbaijan, Belarus, Bosnia and Herzegovina, Botswana, Bulgaria, China, P.R.: Mainland, Congo, Czech Republic, Djibouti, Estonia, Gabon, Georgia, Hungary, Indonesia, Iran Islamic Rep., Jordan, Kazakhstan, Latvia, Lebanon, Lithuania, Macedonia, FYR, Malaysia, Mauritius, Montenegro, Morocco, Philippines, Poland, Romania, Russian Federation, Saudi Arabia, Slovak Republic, South Africa, Sri Lanka, Swaziland, Syrian Arab Republic, Thailand, Tunisia, Turkey, Turkmenistan, Ukraine and Uzbekistan.

Rich non comparators: Australia, Austria, Bahrain, Kingdom of, Belgium, Canada, China, P.R.: Hong Kong, Cyprus, Denmark, Finland, France, Germany, Greece, Ireland, Israel, Italy, Japan, Korea, Kuwait, Luxembourg, Malta, Netherlands, New Zealand, Oman, Portugal, Qatar, Singapore, Slovenia, Spain, Sweden, United Arab Emirates, United Kingdom and United States.

Poor non comparators: Afghanistan, Bangladesh, Benin, Burundi, Cameroon, Central African Republic, Chad, Comoros, Democratic Republic of Congo, Ghana, Guinea, India, Iraq, Kenya, Kyrgyz Republic, Lao People's Democratic Republic, Lesotho, Liberia, Madagascar, Malawi, Mali, Mauritania, Mongolia, Nepal, Niger, Nigeria, Rwanda, Senegal, Sierra Leone, Somalia, Sudan, Taiwan Prov.of China, Tajikistan, Togo, Uganda, West Bank and Gaza, Yemen, Zambia and Zimbabwe. 
Figure 3.7 plots the percentage of individuals with a bank account against rule of law and each country's Gini coefficient for Latin American and Caribbean countries, countries with similar levels of income (comparators) as well as richer (rich non-comparators) and poorer (poor non-comparators) countries. The relationship with rule of law is strong, although countries in Latin America and the Caribbean appear somewhat more dispersed than comparator countries. There is more overall dispersion in the case of inequality, although Latin America and the Caribbean countries appear to obey the relationship more strongly than some other country groups. For example, rich countries typically have a very high percentage of individuals with bank accounts irrespective of the level of inequality while, in the case of poorer countries, the opposite tends to be true. The negative relationship is then driven by Latin America and the Caribbean and comparator countries.

The FINDEX dataset also includes data at the individual level. Thus, whether a person has a bank account or not can be looked at as a function of individual as well as country level characteristics. Individual characteristics such as age, income, gender and the level of education are all significant determinants of whether an individual has a financial account (see Powell, 2016). Women are significantly less likely to have a formal financial account than men, while richer individuals are more likely to have one. The level of education turns out to be highly significant: individuals with secondary and tertiary education are much more likely to have an account.

Interestingly, the country's overall inequality is not significant. While income is an important determinant of whether a person has a bank account, the country's overall income inequality is not. However, when the Gini coefficient is interacted with income quintiles, from the poorest 20 percent of individuals to the richest 20 percent, the results change. The probability of an individual in a lower income quintile being banked depends greatly on the overall country Gini. Neither the Gini nor the income quintiles by themselves are significant. However, the interaction between the two variables is significant. Individuals of lower income quintiles tend not to be banked particularly when the country's income inequality is high (see Figure 3.8). The more unequal the society, the less likely lower income families are to be banked. Instead, for richer households, a country's income inequality has little bearing on their probability of being banked. 
Figure 3.8 Marginal Impact of Inequality for Different Income Groups

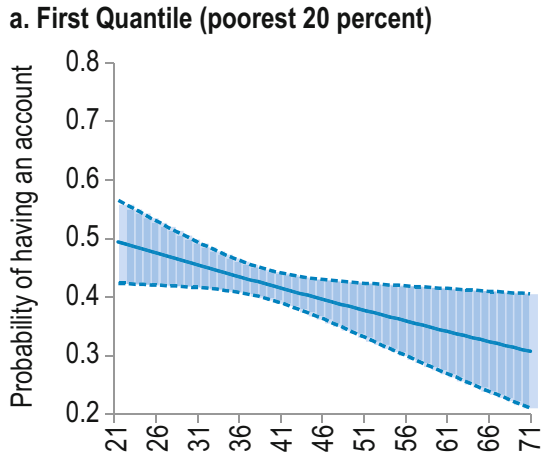

Gini

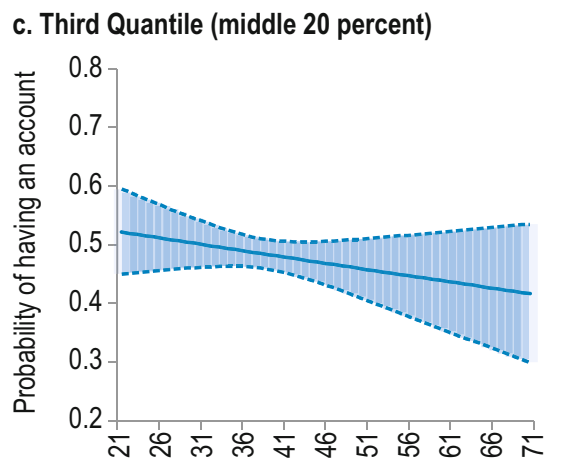

Gini

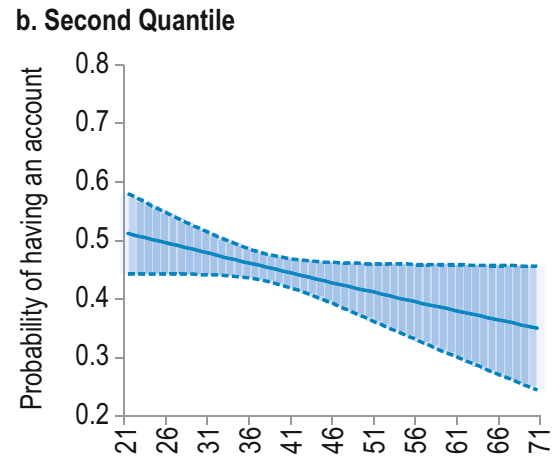

Gini

\section{d. Fourth Quantile}

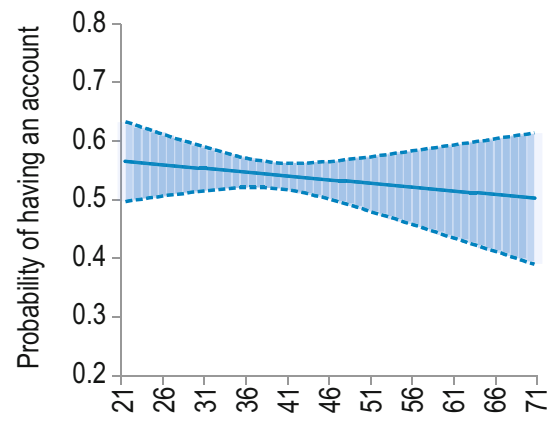

Gini

e. Fifth Quantile (richest 20 percent)

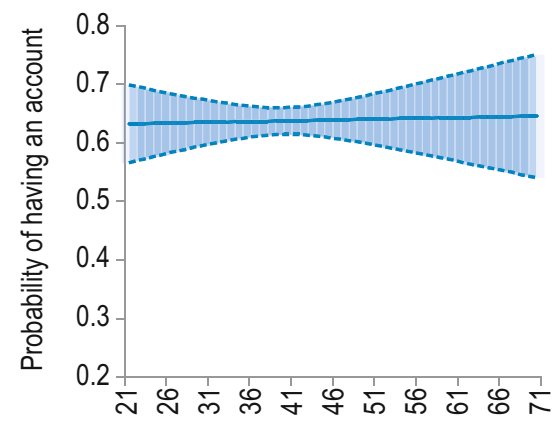

Gini

Source: Authors' calculations using 2011 data from the World Bank's Findex Micro Database.

Note: The figures illustrate that the probability of having a bank account falls sharply for lower income groups as inequality rises while inequality has little effect on rich households. The estimates known as margins plots stem from the estimates of a probit regression and use Findex microdata for the dependent variable (the probability of having an account in a financial institution, post office or microfinancial institution). The explanatory variable in each case is the country Gini coefficient (a measure of inequality) and a set of micro and macro controls. 
This result is consistent with an explanation that factors in the behavior of banks and other financial institutions. If there is a fixed cost for using formal financial institutions for savings, then only people with sufficient resources will use those services. Banks will tend to open branches in communities where richer households will use banking services. If entry barriers to banking are high, the combination of fixed costs and economic inequality may limit the size of banking systems. The result is a financial system that remains relatively small and inefficient and caters largely to wealthier households. Regional inequalities may exacerbate this pattern. In a larger country, banks will naturally locate in areas where richer households reside. Financial institutions may steer clear of poorer areas, leaving poorer households to travel larger distances and face even higher costs in order to be banked. The location decision of banks, coupled with fixed and variable transport costs and economic inequality, leads to a banking sector focused on wealthier households of limited size and hence of higher costs, concentrated in specific geographic locations. A large share of poorer households are left with no banks nearby and are very likely unbanked.

\section{The Link between Financial Access and Savings: The Case of Mexico}

Typically, empirical work suggests that saving is determined by a set of country-level variables and individual or household characteristics. This type of analysis suggests that saving is low in the region due to macroeconomic uncertainty, weak institutions, or low household income, for example. ${ }^{26}$ A drawback of this type of analysis is that it ignores the link between savings behavior and financial access. Without finer, withincountry information, it is impossible to tease out the nature of the link between the two. It is generally assumed that financial access is driven by the same factors that also govern savings.

At the other extreme, a body of literature considers specific interventions that frequently involve improving access to financial services. In general, these studies find that such interventions may well result in greater use of financial services-both credit and saving instruments (see Chapter 9).

There is comparatively less literature on how financial presence (or access) affects saving behavior in an entire country. ${ }^{27}$ There are two main reasons why such analyses have not been attempted. First, published 
household surveys typically do not include information on the location of the household. Second, good information on the precise location of different types of financial services also may not be available. Mexico does have the requisite information, however, and allows for an analysis not only of how financial access affects saving behavior, but also of how financial institutions may make location decisions. Moreover, Mexico is a large country with considerable heterogeneity and has enjoyed significant financial deepening (see Figure 3.9).

Mexico is thus an ideal country to consider the links between financial access and savings. Interestingly, the distribution of financial institutions by municipality is highly skewed. Some municipalities have many financial institutions but many municipalities have just one or none at all (see Figure 3.10). ${ }^{28}$

Naturally, there is a big divide between urban and rural areas. Many urban municipalities have numerous financial institutions, while many rural municipalities have none at all. ${ }^{29}$ Moreover, access to a financial institution varies considerably depending on household income. Indeed, some 93 percent of households in the top decile have relatively easy access to a financial institution (defined as at least one institution in their locality), while those in lower income deciles do not. For example, only 28 percent of households in the lowest income decile have a financial institution nearby (see Figure 3.11). ${ }^{30}$

\section{Figure 3.9 The Process of Financial Deepening in Mexico}

a. Year 2009

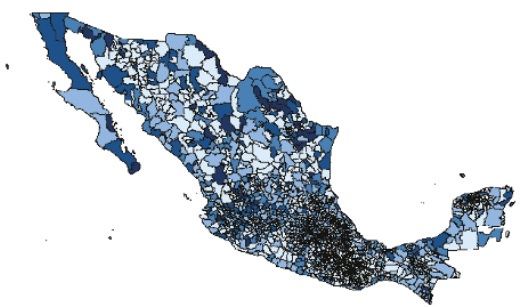

No Branches

(1.07-1.71] per 10,000 inhabitants

口(2.53-132.45] per 10,000 inhabitants b. Year 2013

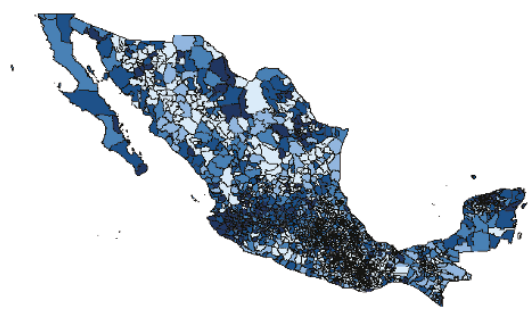

(0-1.07] per 10,000 inhabitants

- (1.71-2.53] per 10,000 inhabitants

Source: Authors' elaboration based on Powell and Székely (2015).

Note: Territorial shading illustrates the number of bank branches per 10,000 inhabitants at the municipal level in Mexico. The cut-off points were obtained by generating quartiles according to the 2013 distribution, excluding the municipalities that do not have a bank branch. 
Figure 3.10 Financial Institutions per Inhabitant in Mexican Municipalities in $\mathbf{2 0 1 2}$

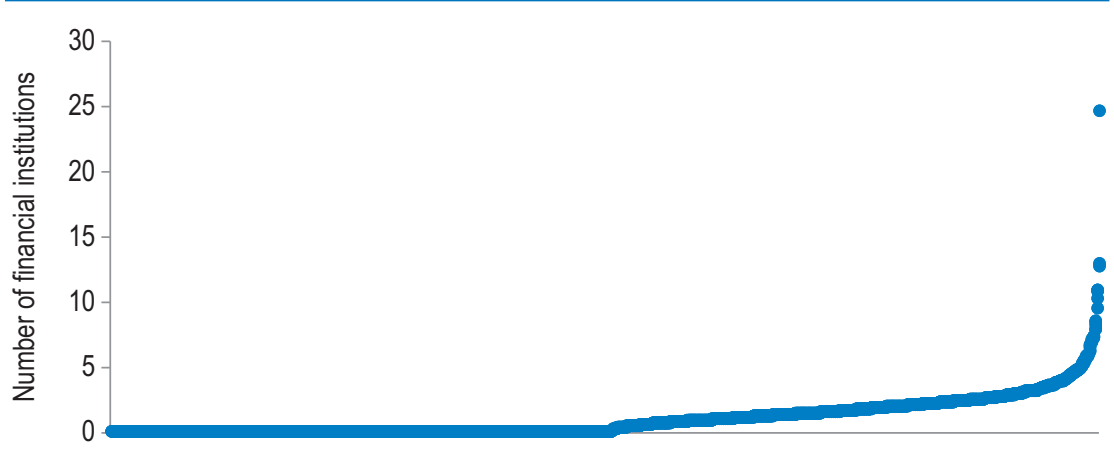

Municipalities ordered by number of financial institutions per 10,000 inhabitants

Source: Authors' elaboration based on Powell and Székely (2015).

Banks will naturally tend to open where they expect to find a market for their services. The number of financial institutions increases in municipalities with fewer poorer households. Moreover, crime rates seem to be positively related with financial institution presence. One explanation may be that in high crime areas, it is more important to keep savings safe

Figure 3.11 Percentage of Households with Access to Financial Institutions by Income Decile, Mexico

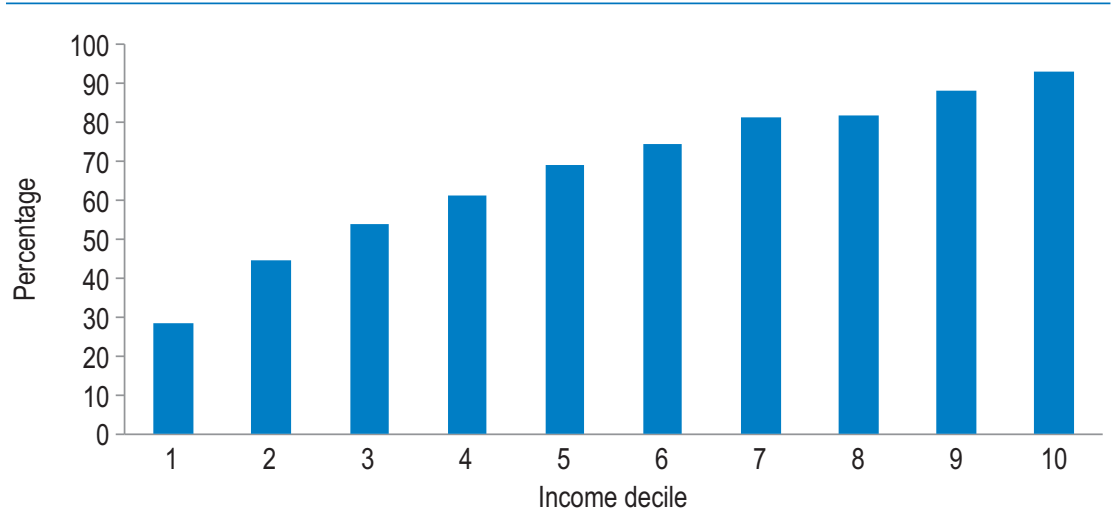

Source: Authors' elaboration based on Powell and Székely (2015).

Note: Includes 2012 data from the Encuesta Nacional de Ingresos y Gastos de los Hogares (ENIGH), 2013 data from the National Dictionary of Economic Units, and 2013 data from the National Banking Commission. 
in a bank rather than at home. Municipal efficiency is also correlated with higher financial presence (see Powell and Székely, 2015).

Interestingly, the presence of a high school is associated with a larger bank presence. Not every municipality in Mexico has a high school. Municipalities are generally keen to obtain such an honor, which may be awarded by the state or federal authorities. One explanation for this relationship is that more people circulate in municipalities with high schools; parents transport their children back and forth to school, and teachers and other personnel come and go to work. Thus, placing a branch in an area with a school rather than one without a school brings greater convenience to a larger number of people. It reduces transaction costs, or what is referred to as "shoe-leather" costs. The decision as to where schools are located is not automatic; location decisions appear to be driven as much by politics as by any other factor. These considerations potentially make school location a useful variable to explain financial presence that is not directly related to savings. ${ }^{31}$

How does financial presence affect savings decisions? To research this question, several years of household surveys and information regarding financial presence were matched at the municipality level. $A$ difficulty is that banks will locate where they think households will use their services. Hence, the measures of financial presence are not used directly. Rather what is used is the estimated financial presence using the preferred proxy: namely, high school presence. As the location of high schools is unrelated per se to savings behavior directly but is a good predictor of bank presence, it appears to be a valid instrument for this analysis. ${ }^{32}$ The main result is that financial savings do indeed increase with financial presence where financial presence is estimated using high school presence as a proxy (see Powell and Székely, 2015).

In theory, the effect could go either way. With financial institutions close by, households might save less, as they might then have more opportunities to borrow in case of a negative shock. However, the results suggest that the lower costs of greater proximity to a financial institution outweigh this potential effect.

\section{The Missing Link}

Ideally, people save, deposit their savings in financial institutions, which in turn allocate those savings to productive investments in the economy that fuel overall growth and development. Financial intermediaries are, 
therefore, the crucial link between savers and investors. Unfortunately, in Latin America and the Caribbean, financial intermediation is the missing link, the break in the chain between savings and investment that determines the quality of saving in the region. Increasing access and use of financial institutions are keys to deepening the financial system and ensuring that Latin America and the Caribbean generate not only more, but better, saving. 


\section{Notes}

1 For an in-depth analysis of credit constraints, see IDB (2004). For a more recent treatment, see Didier and Schmukler (2014).

2 This definition of the roles of financial systems borrows from Levine (2005), who followed the earlier work of Nobel prize-winner Robert Merton in constructing this list.

3 For discussion on this point, see Allen and Gale (2000).

4 For information about how corporate governance differs around the globe, see OECD (2015b). For a discussion of comparative financial systems and the link to corporate governance, see Mayer (1998) and Allen and Gale (2000). For an account of how the global financial crisis has prompted new interest in finance and corporate governance issues, see Hopt (2011).

5 For a discussion of the alternative disciplining roles of banks and capital markets, see Mayer (1996) and Franks, Mayer, and Renneboog (2001).

6 Rajan and Zingales (2003) provide an interesting discussion on a similar phenomenon in continental Europe.

7 For a review of the literature, see Levine (2005).

8 In a panel regression analysis, bank deposits were regressed on the assets under management of capital market institutions (pension funds, insurance companies, and mutual funds) with both time and country fixed effects. If the coefficient on the assets under management of capital market institutions is positive and significant, then the hypothesis that they are substitutes to banks may be rejected. This was indeed the result. The hypothesis that Latin American and Caribbean countries may differ from comparator countries was also rejected.

9 Many of these issues are discussed in more depth in OECD (2015b).

10 See in particular Dewatripont and Tirole (1994), who argue that small investors would have little chance in disciplining firms, but banks that pool such investors may attempt to play that role. They also argue that financial regulation is needed to discipline banks, and refer to this as the "representation hypothesis" rationale for financial regulation.

11 See IDB (2004); Chong and Pagés (2010); Didier and Schmukler (2014).

12 Berger and Mester (1997) find significant scale economies in U.S. banking. Anderson and Jõeveer (2012) also argue in favor of scale 
economies, and employ a novel approach considering the rents accruing to shareholders versus bankers. Other studies find less evidence for scale economies in banking. For a set of papers on this issue, see Feldman (2010, Mester (2010), and DeYoung (2010). Economies of scale are normally considered on the basis of individual institutions; this raises the question of competition. A small number of larger banks may be efficient in reducing fixed costs, but then each may have extensive market power. A larger number of banks may promote competition, but may lead to an inefficient repetition of fixed costs.

13 In the late 1800s, Bagehot (1873, 3-4) argued that a major difference between England and poorer countries was that in England, the financial system could mobilize resources for "immense works."

14 The World Bank's FINDEX dataset is available at http://datatopics. worldbank.org/financialinclusion/.

15 Of course, there are exceptions. The Unit Trust Corporation of Trinidad and Tobago is a cooperative, is highly integrated into the financial system, and has assets of close to 10 percent of the country's GDP. Creditcoop of Argentina is also a cooperative and is highly integrated into the country's financial system; it is regulated and supervised by the central bank and the superintendence of financial and exchange entities as a regular commercial bank.

16 See Sirri and Tufano (1995); Acemoglu and Zilibotti (1997).

17 See Aizenman, Cavallo, and Noy (2015).

18 Evidence for Colombia comes from ongoing background work by Camacho and Hofstetter employing the ELCA household surveys (Universidad de los Andes) and complementary data sources.

19 The figure considers the main saving instrument for each household, defined as the one with the highest stock.

20 For the most part, surveyed households in these countries (which are low- and middle-income households) save either formally or informally, but not both ways.

21 Data were collected for five countries in Latin America (Brazil, Chile, Colombia, Ecuador, and Mexico) and seven other countries (the Czech Republic, Hungary, the Republic of Korea, the Philippines, Poland, South Africa, and Thailand). The analysis can be performed only for those countries that have sufficiently disaggregated national account data. In particular, a detailed breakdown of the capital and financial accounts by institutional sector (households, government, corporations, foreign) is required. These 12 countries satisfied these requirements. 
22 Household funds that are intermediated formally include "financial deposits" (including cash holdings), "funds allocated to insurance and pension funds," and "debt security holdings." Household funds that are not intermediated or are savings parked in informal instruments include "direct ownership of firms" (which comprises shares and other equity holdings) and the residual category, "acquisition of other financial assets."

23 The other subcomponents of "equity" are purchases of equity in firms listed on the stock market, and purchases of shares through mutual funds. It is not likely that either one of these two explains the difference between Latin America and the comparator group. First, households participate little in the stock market in Latin America. On average, only 1 percent of the population in a select group of countries in the region owns shares of publicly listed companies directly, while among four countries in Emerging Asia, the ratio is 20 percent (see Grout, Megginson, and Zalewska, 2009). Second, for a subset of countries for which data are available, there is no difference in the households' investments in mutual funds between countries in the two groups. In Brazil, Chile, and Colombia, households use 4.6 percent of total funds to purchase mutual funds, while comparator countries use 4.5 percent.

24 National accounts may record activities like purchasing a durable good like a refrigerator or a truck as consumption; thus some of these activities may not be included as savings, even though such activities are a form of savings, from the standpoint of the individual. After "not enough money" and "family member already has an account," cost and distance were the most common reasons respondents gave for not having a bank account, with 23 percent and 20 percent giving those replies, respectively (World Bank, 2014a, Figure 1.14).

${ }^{26}$ For a recent empirical analysis along these lines, see Grigoli, Herman and Schmidt-Hebbel (2015).

27 Aportela (1999) and Ruiz (2013) both consider the expansion of (different) specific financial institutions in Mexico and the impact on households' financial decisions. For further discussion, see Chapter 11.

28 A point of access here is a bank branch, a correspondent bank location, or an automatic teller machine (ATM).

29 Powell and Székely (2015) provide further statistics regarding the location of financial institutions, correspondent banks, and ATMs. 
30 A locality is a subdivision of a municipality. There are more than 2,400 municipalities in Mexico and over 190,000 localities.

31 In other words, it may be a useful "instrument" in an "instrumental variables" analysis.

32 A further "matching methodology" was also pursued as a robustness test, and the same results were found to hold. For further details and for further robustness tests, see Powell and Székely (2015).

This chapter is distributed under the terms of the Creative Commons Attribution-NonCommercial-NoDerivatives $3.0 \quad$ IGO license (http://creative commons.org/licenses/by-nc-nd/3.0/igo/) and may be reproduced with attribution to the Inter-American Development Bank (IDB) and for any non-commercial purpose. No derivative work is allowed.

Any dispute related to the use of the works of the IDB that cannot be settled amicably shall be submitted to arbitration pursuant to the UNCITRAL rules. The use of the IDB's name for any purpose other than for attribution, and the use of IDB's logo shall be subject to a separate written license agreement between the IDB and the user and is not authorized as part of this CC-IGO license. Note that the link provided above includes additional terms and conditions of the license.

The images or other third party material in this chapter are included in the work's Creative Commons license, unless indicated otherwise in the credit line; if such material is not included in the work's Creative Commons license and the respective action is not permitted by statutory regulation, users will need to obtain permission from the license holder to duplicate, adapt or reproduce the material. 